\title{
The Septation of the Sphenoidal Air Sinus. A Cadaveric Study
}

\author{
Septación del Seno Esfenoidal. Investigación Cadavérica
}

\author{
Ntombifuthi P. Ngubane $^{1}$; Lelika Lazarus ${ }^{1}$; Carmen O. Rennie ${ }^{1}$ \& Kapil S. Satyapal $^{1}$
}

NGUBANE, N. P.; LAZARUS, L.; RENNIE, C. O. \& SATYAPAL, K. S. The septation of the sphenoidal air sinus. A cadaveric study. Int. J. Morphol., 36(4):1413-1422, 2018.

SUMMARY: The purpose of this study was to investigate the sphenoidal sinus septation in a select South African population, and document the relation of the number and location of the septa to the structures intimately related to the sinus. The intersinus and intrasinus septa of the sinus, the number and attachments of the septa were recorded from forty five cadaveric head specimens. The sphenoidal sinus intersinus septa were recorded as follows: Type 0 (absent septum) in $7.5 \%$, Type 1 (single septum) in $65 \%$ and Type 2 (double septa) in $22.5 \%$ of cases. The incidence of intersinus septa deviating to the left was prevalent; hence, the right sphenoidal sinus was dominant. The occurrence of intrasinus septa was observed in $93.3 \%$ of cases, with a higher prevalence in males. The intrasinus septa formed cave like chambers on the sinus walls in $65.6 \%$ cases. Incidences of the intersinus septa attaching to sella turcica (ST) $(46.25 \%)$ were prevalent compared to cases where they attached to the internal carotid artery (ICA) $(6.25 \%)$, maxillary (MN) $(1.25 \%)$ and vidian (VN) $(1.25 \%)$ nerves. However, the intrasinus septa attached more to the ICA (52.63\%) compared to their attachment to the other neurovascular structures (ST - 26.32\%; MN - 5.36\% and VN-2.63\%). Surgeons need to be aware of the complex anatomical variations of the sphenoidal sinus septation when performing endoscopic endonasal transsphenoidal surgeries.

KEY WORDS: Sphenoidal sinus; Paranasal sinus; Septation; Cadaveric head specimens; Endoscopic endonasal transsphenoidal procedures.

\section{INTRODUCTION}

The nasal cavity is surrounded by a number of bones, and within some of these bones are air-filled cavities known as paranasal sinuses (Van Cauwenberge et al., 2004; Kayalioglu et al., 2005). The hollow space located within the body of the sphenoid bone is called the sphenoidal sinus (Singh et al., 2016). The sphenoidal sinus is said to vary exceptionally in shape and localization (Kayalioglu et al.); and it is also divided into two unequal parts by an asymmetric bony intersinus septum which lies on the vertical plane of the sinus (Hamid et al., 2008; Hewaidi \& Omami, 2008; Lu et al., 2011). In some cases there may be more than one intersinus septa dividing the sinus, and intrasinus (accessory or partial) septa may also be present (Sareen et al., 2005; Kapur et al., 2012; Chougule \& Dixit, 2014; ELKammash et al., 2014; S`tokovic' et al., 2016). The sphenoidal sinus is completely divided by the intersinus septa whilst the intrasinus septa are contained inside the sinus and do not completely divide it (Rennie et al., 2017). The occurrence of intrasinus septa leads to the subdivision of the sphenoidal sinus, and this subdivision results in the formation of sphenoid sinus recesses (Sareen et al.; Tan \& Ong, 2007; Lazaridis et al., 2010). According to Lazaridis et al. intrasinus or partial septa occurrence is due to the resistance to pneumatization of some of the bones in the sphenoidal sinus.

The sphenoidal sinus septum is a significant surgical landmark when endoscopic endonasal transsphenoidal approaches are performed, as it may attach to crucial structures such as the optic canal and internal carotid artery (Chong et al., 1998; Unal et al., 2006; Idowu et al., 2009; Kapur et al.; Awadalla et al., 2015). During the removal of pituitary tumors via the transsphenoidal approach, spaces of the nasal cavity and sphenoidal sinus are used to access the center of the skull base. In this process, the sphenoidal sinus intersinus septa must be located and in the latter removed so surgical instruments may reach the sella turcica which in the later stage is also opened with the aid of microsurgical instruments, (Casiano, 2002; S`tokovic' et al.). 
The sphenoidal sinus has been investigated in various regions in the world; however there is paucity of studies in the South African region. Due to variations of the sphenoidal sinus, it is of great significance that the septation of the sinus is thoroughly understood in order to ensure safe endoscopic surgical approaches, especially in cases whereby intraoperative neuronavigation is abstract (Kapur et al.).

Most studies reported on multiple septation (Kayalioglu et al.; Sareen et al.; Tan \& Ong; Hamid et al.; Fasunla et al., 2012; Kapur et al.; Chougule \& Dixit; ELKammash et al.; S`tokovic' et al.); and some authors like Fasunla $e t$ al. also reported on cases whereby septation was not observed in the sphenoidal sinus. According to some authors, the sphenoidal sinus septum is commonly found deviating to the right or to the left and rarely found located in the center or midline (Tan \& Ong; Fasunla et al.). The bending or deviation of the sinus septum towards one of the sides, results in the sphenoidal sinuses being unequal, with the larger sinus termed the 'dominant' sinus (Anusha et al., 2014; Vidya \& Raichurkar, 2015). Based on the previous studies, the sinus septa is prevalently found attaching to the bulge of internal carotid artery (Unal et al.; Hamid et al.; Chougule \& Dixit; Awadalla et al.).

This study aimed to investigate within the South African population the septation of the sphenoidal sinus (intersinus and intrasinus) and the relationship between the sinus septa and the bony coverings of the optic nerve, internal carotid artery and other structures (i.e. maxillary and vidian nerves) in which the septa may be found to be in contact with.

\section{MATERIAL AND METHOD}

The specimens used in this study were obtained using embalmed cadaveric material from the Discipline of Clinical Anatomy, School of Laboratory Medicine and Medical Sciences, College of Health Sciences, Westville and Nelson R Mandela School of Medicine campuses, University of KwaZulu Natal. Ethical clearance was obtained from within the University (Clearance number: BE478/17). Forty five embalmed cadaveric specimens were used for this study (male $\mathrm{n}=26$; female $\mathrm{n}=19$ ). The population distribution was 39 White and 6 Black individuals. The age range for all specimens was $22-97$ years with an average of 72 years.

To access the sphenoidal sinus; the calvaria and brain were removed. Next, the roof of the sinus was carefully removed to gain access to the sphenoidal sinus from above (axial view); and in all specimens but $5(n=40)$, the septation was then investigated. The number and orientation of the intersinus and intrasinus septa, as well as the attachment of each septum (to check for relationship between sinus septa and the neurovascular structures surrounding the sinus) was recorded. Digital images of all observations were captured using a Sony ES30 digital camera (12.2 mega pixel) at each stage of dissection. Schematic illustrations were used to classify the septation patterns observed. The sphenoidal sinuses were reviewed in both the axial section and also in the mid-sagittal section in order to investigate for further intrasinus septa.

Intersinus investigation: Out of the total of 45 cadaveric specimens used for this study, 5 were excluded since they were already cut mid-sagittally and hence it was not clear whether they had intersinus septa present or not. Therefore, only 40 sphenoidal sinuses (axial views) were investigated in this section with 18 females and 22 males investigated. The population distribution was then 34 white and 6 black individuals with an age of 22 - 97 years and an average age of 69 years.

Intrasinus investigation: All 45 cadaveric specimens were included in this section of the study since both the axial and the mid-sagittal sections were used to bilaterally study the intrasinus septa of the sphenoidal sinus ( $\mathrm{n}=90$ sides).

Statistical analysis: With the use of SPSS (Statistical Package for Social Sciences) version 25.0 (IBM® SPSS Inc., Chicago, Illinois, USA); the Pearson Chi-Square test, test for proportion and cross tabulations were adopted to statistically test for association and to determine the level of significance between the sphenoidal sinus septa, laterality and sex. A p value of $\leq 0.05$ was considered to be statistically significant.

\section{RESULTS}

In this investigation, it was confirmed that indeed the sphenoidal sinus septation varies to a great extent. In relation to crista galli (CG), the intersinus septum (if present) was either located centrally or in the midline (in line with the CG) or deviated the left or right of the CG.

Intersinus Septa. A total of 40 axial head specimens were used to record the incidence of the intersinus septa. The intersinus septa was absent in $7.5 \%(n=3 / 40)$ of cases, and this incidence was classified as Type 0 . When present, the intersinus septum was classified into 2 major types, viz. Type 1: presence of a single intersinus septum (65\%) (Table I) and Type 2: presence of double intersinus septa (22.5\%) (Table II). No cases were recorded where intersinus septa were more than 2 in number. 
Table I. Classification types of single intersinus septa.

Incidence (\%)

Table II. Classification types of double intersinus septa.

Classification

The 2 major types were both further divided into 3 subtypes, viz. Type 1(a) (central septum) which was observed in $7.5 \%(n=3 / 40)$ of cases, Type 1(b) (left deviated septum) occurred in $30 \%(n=12 / 40)$ of cases and Type 1(c) (right deviated septum) was observed in $22.5 \%(n=9 / 40)$ of cases (Fig. 1, Table I). Type 2(a) (parallel septa) occurred in $7.5 \%(\mathrm{n}=3$ / 40) of cases, Type 2(b) (septa curving or slanting towards sinus midline) was observed in $5 \%(\mathrm{n}=2 / 40)$ of cases and the incidence of Type 2(c) (septa curving or slanting towards sinus lateral walls) was recorded in $2.5 \%$ $(n=1 / 40)$ of cases (Fig. 2, Table II). In $17.5 \%(n=7 / 40)$ of cases, other intersinus septa variations which did not fall in any of the classifications described above were observed, $5 \%$ $(\mathrm{n}=2 / 40)$ of cases were single intersinus septum $1(\mathrm{v})$ and $12.5 \%$ $(n=5 / 40)$ of cases were double intersinus septa 2(v) (Fig. 3).

The intersinus septum was not always observed as a flat and regular bone, and in $45 \%$ of cases it was found to have an irregular shape (Fig. 4). Single intersinus septum occurrence was observed in $61.1 \%(n=11 / 18)$ of females, and in $68.2 \%(n=15 / 22)$ of males with Type 1(b) being the prevalent type in both sexes. On the other hand, occurrence of double intersinus septa was observed in $27.8 \%(n=5 / 18)$ of females and $27.3 \%(n=6 / 22)$ of males (Table III). The correlation between the type of the sphenoidal intersinus septa and sex yielded p-values of 0.517 and 0.860 for Type 1 and Type 2, respectively (Table IV).

Intrasinus (accessory or partial) septa. The number of intrasinus septa ranged from $0-5$, with no cases of more than 5 accessory septa encountered in one side of the sphenoidal sinus (neither on the left nor the right side). The absence of intrasinus septa was observed in 6.7 $\%(n=6 / 90)$ of cases; a single intrasinus 

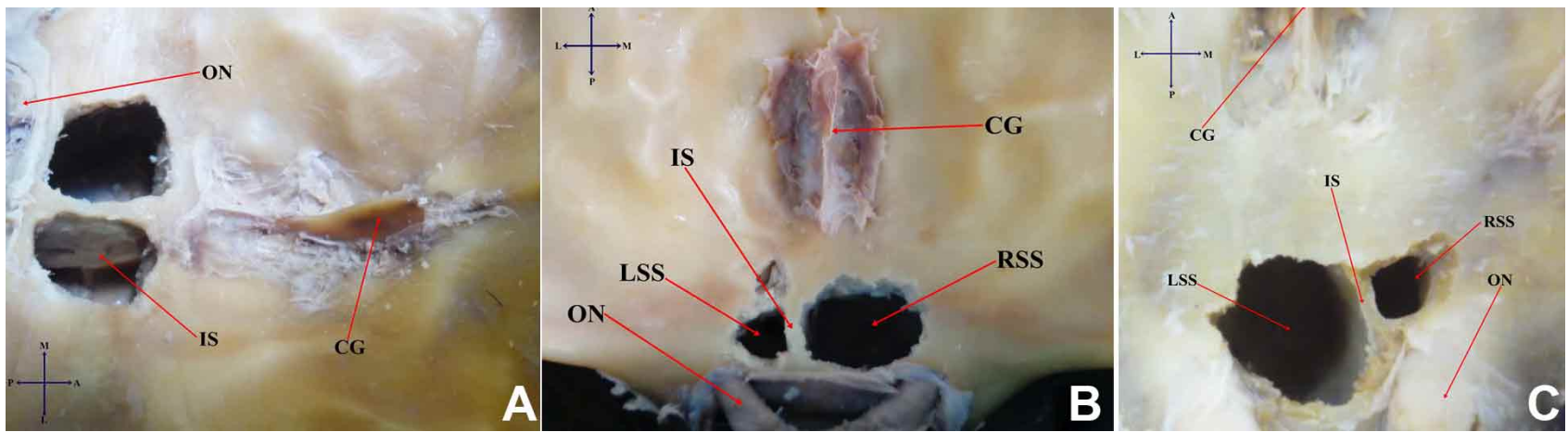

Fig 1. Classification types of single intersinus septa (axial view). Type 1 A. Intersinus septum in line with crista galli and straight. Type 1 B: Intersinus septum deviating to the left and slightly curving towards the lateral wall of left sinus. Type $1 \mathrm{C}$ : Intersinus septum deviating to the right and slanting towards the optic nerve and internal carotid artery bulges. KEY: Anterior (A); Posterior (P); Medial (M); Lateral (L); Optic Nerve (ON); Intersinus Septum (IS); Crista Galli (CG); Left Sphenoidal Sinus (LSS); Right Sphenoidal Sinus (RSS)
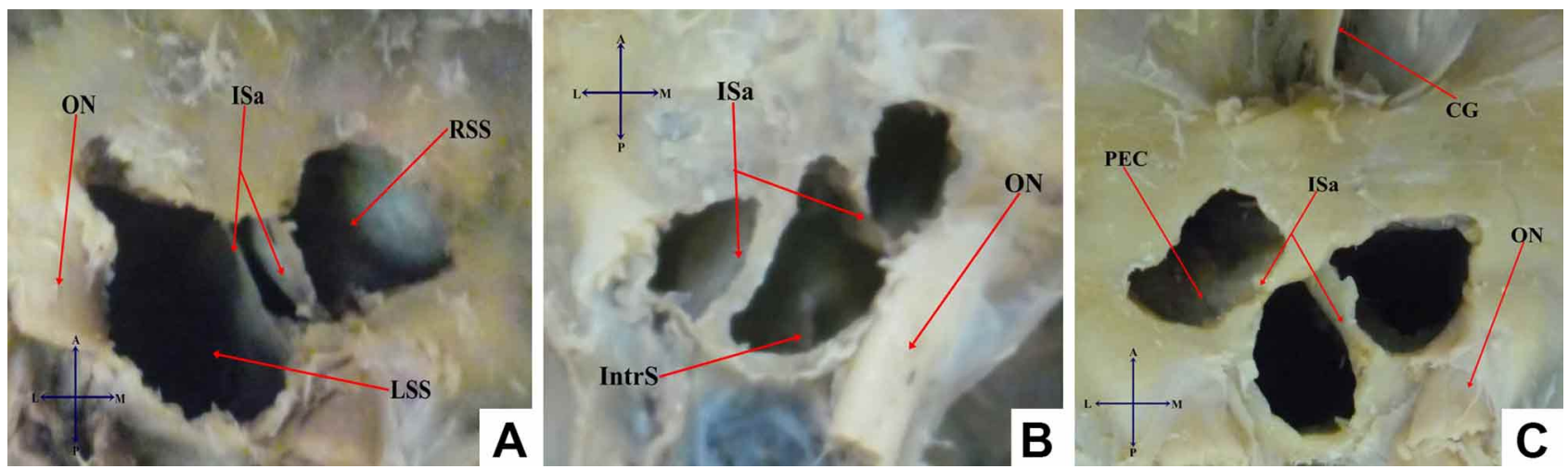

Fig 2. Classification types of double intersinus septa (axial view). Type 2: Parallel intersinus septa A; both intersinus septa curving towards the midline B; one intersinus septum curving towards the lateral wall of the sinus and one slanting towards the optic nerve $\mathrm{C}$. KEY: Anterior (A); Posterior (P); Medial (M); Lateral (L); Optic Nerve (ON); Intersinus Septa (ISa); Intrasinus Septum (IntrS); Crista Galli (CG); Left Sphenoidal Sinus (LSS); Right Sphenoidal Sinus (RSS); Posterior Ethmoidal Cells (PEC)
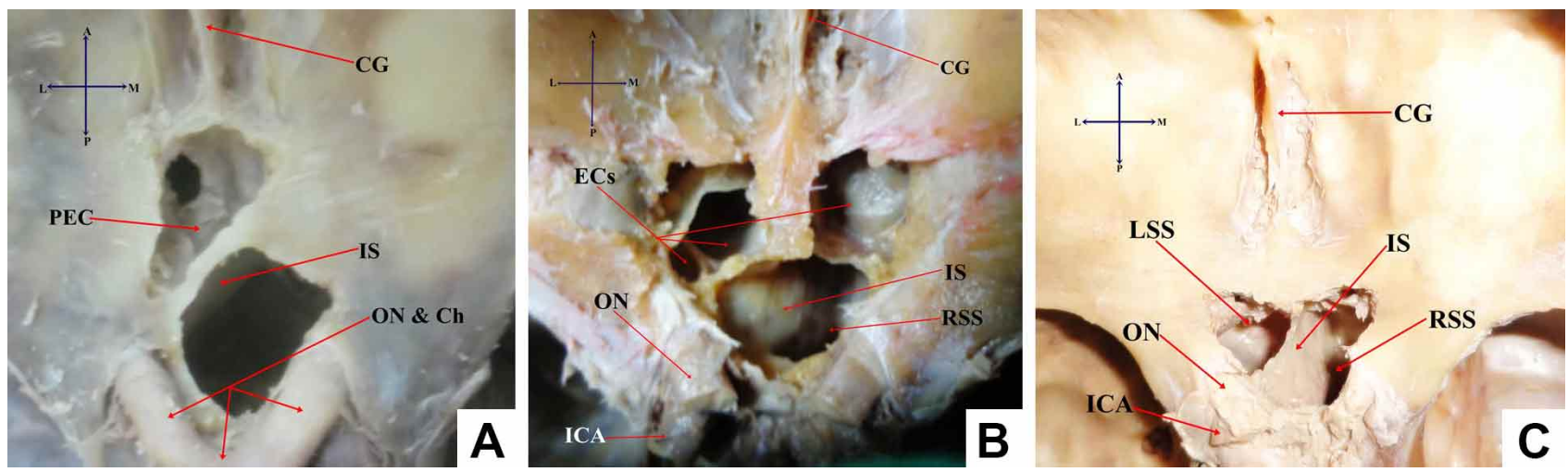

Fig 3. Other variations of the intersinus septa (axial view). A. Intersinus septum slanting from the right lateral wall towards the left lateral wall of the sinus and diving the sinus to superior and inferior parts instead of left and right parts; B. Intersinus septum curving from the midline to the left lateral wall of the sinus, this way covering the entire left sphenoidal sinus; $\mathrm{C}$. Intersinus septum slanting and curving from the right side of crista galli towards the optic nerve on the left lateral wall of the sinus. KEY: Anterior (A); Posterior (P); Medial (M); Lateral (L); Optic Nerve (ON); Optic Chiasma (Ch); Internal Carotid Artery (ICA); Intersinus Septum (IS); Crista Galli (CG); Left Sphenoidal Sinus (LSS); Right Sphenoidal Sinus (RSS); Posterior Ethmoidal Cell (PEC); Ethmoidal Cells (ECs)

septum occurred in $45.6 \%(\mathrm{n}=41 / 90)$ of cases; two intrasinus septa were observed in $33.3 \%(\mathrm{n}=30 / 90)$; three intrasinus septa were present in $12.2 \%(\mathrm{n}=11 / 90)$ of cases and the occurrence of four and five accessory septa was observed each in $1.1 \%(\mathrm{n}=1 / 90)$ of cases (Table V). The occurrence of intrasinus septa on the left and on the right side was found 
Table III. Distribution of the sphenoidal sinus intersinus septa (sex).

\begin{tabular}{ccc}
\hline Type of Intersinus Septum & \multicolumn{2}{c}{ Incidence $(\%)$} \\
& Female & Male \\
\hline 0 & $2(11.11)$ & $1(4.55)$ \\
$1(\mathrm{a})$ & $1(5.56)$ & $2(9.09)$ \\
$1(\mathrm{~b})$ & $5(27.78)$ & $7(31.82)$ \\
1 (c) & $4(22.22)$ & $5(22.73)$ \\
$2(\mathrm{a})$ & $1(5.56)$ & $1(4.55)$ \\
$2(\mathrm{~b})$ & $1(5.56)$ & $2(9.09)$ \\
$2(\mathrm{c})$ & $1(5.56)$ & 0 \\
$2(\mathrm{v})-$ other variations & $1(5.56)$ & $1(4.55)$ \\
other variations & $2(11.11)$ & $3(13.64)$ \\
\hline Total & $18(100)$ & $22(100)$ \\
\hline
\end{tabular}

Table IV. Association between the sphenoidal sinus intersinus type and sex.

\begin{tabular}{cccc}
\hline $\begin{array}{c}\text { Type of Intersinus } \\
\text { Septa }\end{array}$ & Female & Male & $P$-value \\
\hline 0 & 11 & 15 & 0.157 \\
1 & 5 & 6 & 0.860 \\
\hline
\end{tabular}

Table V. Distribution of the sphenoidal sinus intrasinus septa (sex)

\begin{tabular}{ccccc}
\hline $\begin{array}{c}\text { Number of } \\
\text { intrasinus septa }\end{array}$ & Female & Male & Overall & $P$-value \\
\hline 0 & $1(2.63)$ & $5(9.62)$ & $6(6.67)$ & 0.1917 \\
1 & $17(44.74)$ & $24(46.15)$ & $41(45.56)$ & 0.8450 \\
2 & $14(36.84)$ & $16(30.77)$ & $30(33.33)$ & 0.5485 \\
3 & $5(13.16)$ & $6(11.54)$ & $11(12.22)$ & 0.8177 \\
4 & 0 & $1(1.92)$ & $1(1.11)$ & 0.8220 \\
5 & $1(2.63)$ & 0 & $1(1.11)$ & \\
\hline Total & $38(100)$ & $52(100)$ & $90(100)$ & \\
\hline
\end{tabular}

Table VI. Distribution of the sphenoidal sinus intrasinus septa (laterality)

\begin{tabular}{ccccccc}
\hline \multirow{2}{*}{ No. of intrasinus septa } & \multicolumn{3}{c}{ Female } & \multicolumn{2}{c}{ Incidence (\%) } \\
& Male & \multicolumn{2}{c}{ Overall } \\
\cline { 2 - 6 } & Left & Right & Left & Right & Left & Right \\
\hline 0 & $1(5.26)$ & 0 & $3(11.54)$ & $2(7.69)$ & $4(8.89)$ & $2(4.44)$ \\
1 & $6(26.58)$ & $11(57.89)$ & $13(50.00)$ & $11(42.31)$ & $19(42.22)$ & $22(48.89)$ \\
2 & $9(47.37)$ & $5(26.32)$ & $8(30.78)$ & $8(30.78)$ & $17(37.78)$ & $13(28.89)$ \\
3 & $2(10.53)$ & $3(15.79)$ & $2(7.69)$ & $4(15.38)$ & $4(8.89)$ & $7(15.56)$ \\
4 & 0 & 0 & 0 & $1(3.85)$ & 0 & $1(2.22)$ \\
5 & $1(5.26)$ & 0 & 0 & 0 & $1(2.22)$ & 0 \\
\hline Total & $19(100)$ & $19(100)$ & $26(100)$ & $26(100)$ & $45(100)$ & $45(100)$ \\
\hline
\end{tabular}

to be equally distributed, with $50 \%(n=45 / 90)$ of cases on each side. However, when distributed in relation to sex groups, $90 \%(n=47 / 52)$ of males were reported to have intrasinus septa on both the left and right sides with incidences of $88.5(n=23 / 26)$ and $92.3 \%(n=24 / 26)$, respectively. The occurrence of intrasinus septa was observed in $94.4 \%(n=37 / 38)$ of females with $100 \%(n=19 / 19)$ on the right and $94.7 \%(n=18 / 19)$ on the left (Table VI). The association between the number of intrasinus septa and sex (male and female) yielded p-values of 0.1917, 0.8450, $0.5485,0.8177$ and 0.8220 for absent septum, one septum, two septa, three septa and for four and above septa, respectively.

The intrasinus septa varied greatly morphologically (Fig. 5); in respect to their origin and insertion to the different walls of the sinus (viz. anterior, posterior, roof and floor). One fascinating phenomena that was observed about the intrasinus septa, was how they formed cave like chambers within the sinus wall (Figs. $5 \mathrm{a}-\mathrm{e}, \mathrm{g}-\mathrm{h}$ ).

Attachment of the septa. The neurovascular structures were observed in the sinus walls as bulges or bony coverings of the structures. The intersinus and the intrasinus septa recorded in this study attached to the bulges formed by sella turcica (ST); internal carotid artery (ICA); maxillary nerve $(\mathrm{MN})$ and the vidian nerve (VN) (Fig. 6). The incidence of the intersinus septa in contact with the ST was observed in $46.25 \%(n=37 / 80)$ of cases (female $=88.89 \%$; male $=95.45 \%$ ). The intersinus septa attached to the bony covering of ICA in 6.25 $\%(\mathrm{n}=5 / 80)$ of cases $($ female $=16.67 \%$; male $=9.09$ $\%)$; and in $1.25 \%(\mathrm{n}=1 / 80)$ of cases (female) each to either the MN the bulge of the VN (Table VII). It must be noted that the VN bulge in some cases may easily be mistaken for one of the accessory septa as it may seem to be of the same thickness as the intrasinus septa or crests (Fig. 6e).
The intrasinus septa in females attached to the ST in $26.32 \%(n=10 / 38)$ of cases $($ left $=10.53 \%$; right $=15.79 \%)$, to the ICA in $52.63 \%$ of cases $(n=20 / 38)($ left $=28.95 \%$; right $=23.68 \%)$, to the $\mathrm{MN}$ in $5.26 \%(\mathrm{n}=2 / 38)$ cases on the left side and to the $\mathrm{VN}$ in $2.63 \%(\mathrm{n}=1 / 38)$ case on the right side. The intrasinus septa in male specimens attached to the ST in $19.23 \%(n=10 / 52)($ left $=8.77 \%$; right $=13.46 \%)$, 

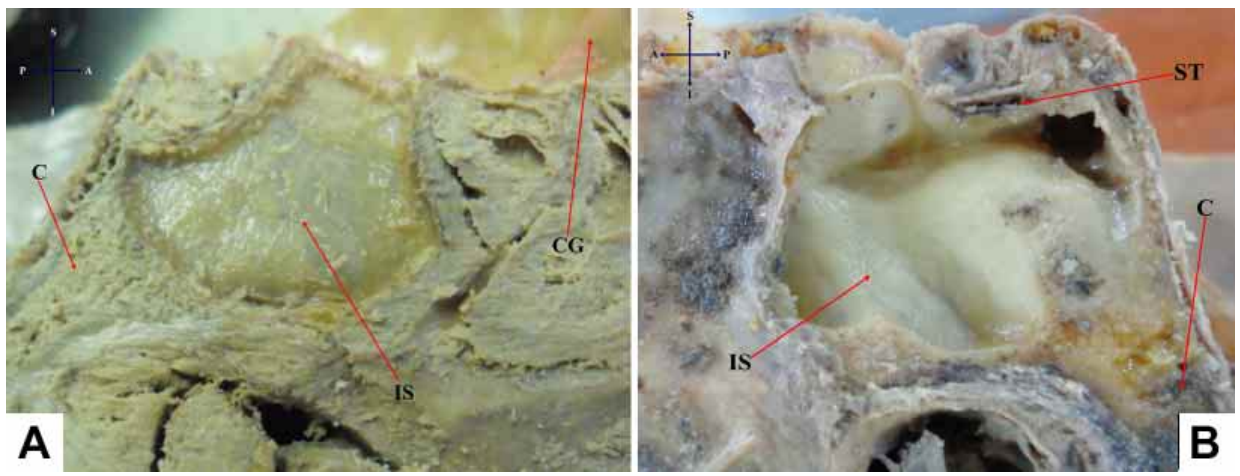

Fig 4. Shapes of the intersinus septa (midsagittal view). A. Flat intersinus septum. B. Irregular intersinus septum. KEY: Anterior (A); Posterior (P); Superior (S); Inferior (I); Intersinus Septum (IS); Crista Galli (CG); Clivus (C); Sella Turcica $(\mathrm{ST})$
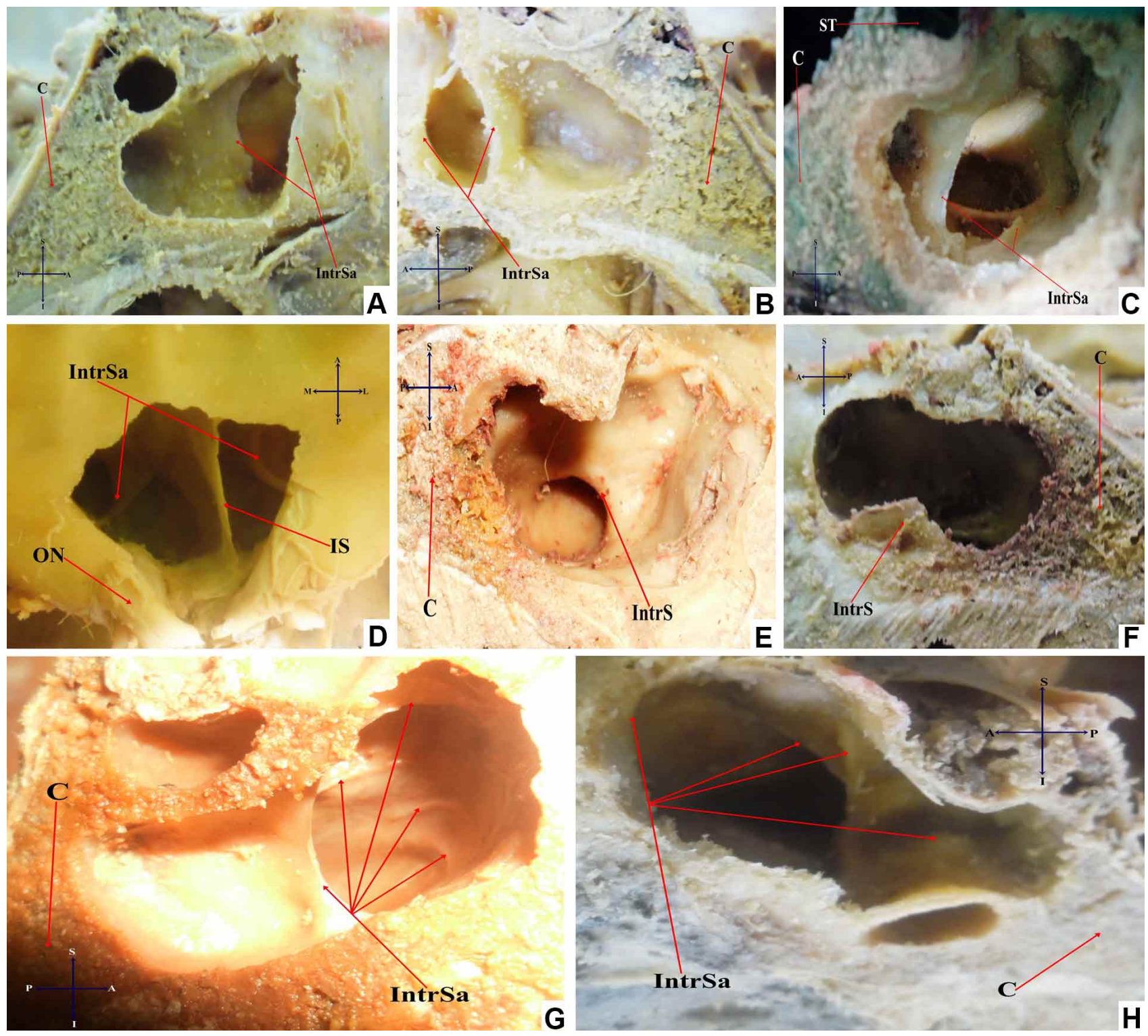

Fig 5. Various types of intrasinus (accessory or partial) septa of the sphenoidal air sinus (axial and midsagittal views). Intrasinus septa arising from the floor of the sinus (C, D \& F), from the posterior wall of the sinus (A, C, E \& G), from the roof $(\mathrm{G})$ and from the lateral wall of the sinus (B \& E). In most cases, the intrasinus septa was found forming cave like chambers inside the sphenoidal sinus (A, B, C, D, E, G \& H). KEY: Anterior (A); Posterior (P); Superior (S); Inferior (I); Intrasinus Septum/Septa (IntrS/Sa); Optic Nerve (ON); Crista Galli (CG); Clivus (C); Sella Turcica (ST) 



Fig 6. Attachments of both intersinus and intrasinus sphenoidal sinus septa (mid-sagittal view). Intersinus septum attaching to sella turcica D. and to internal carotid artery, maxillary and vidian nerves (E). Partial septa attaching to sella turcica (B), internal carotid artery (A \& C) and maxillary nerve (A). KEY: Anterior (A); Posterior (P); Superior (S); Inferior (I); Intersinus Septum (IS); Intrasinus Septum/ Septa (IntrS/Sa); Posterior Ethmoidal Cell (PEC); Internal Carotid Artery (ICA); Maxillary Nerve (MN); Vidian Nerve (VN); Clivus (C); Sella Turcica (ST)

Table VII. Attachments of the sphenoidal sinus septa (intersinus and intrasinus).

\begin{tabular}{lcccccc}
\hline Bulge/Structure & \multicolumn{2}{c}{ Intersinus Septa (\%) } & \multicolumn{3}{c}{ Intrasinus Septa (\%) } \\
& Female & Male & Feft & Right & Left & Right \\
\hline Sella Turcica & $16(17.8)$ & $21(23.3)$ & $4(4.4)$ & $6(6.7)$ & $3(3.3)$ & $7(7.8)$ \\
Internal Carotid Artery & $3(3.3)$ & $2(2.2)$ & $11(12.2)$ & $9(10)$ & $8(8.9)$ & $13(14.4)$ \\
Maxillary Nerve & $1(1.1)$ & 0 & $2(2.2)$ & 0 & $3(3.3)$ & $2(2.2)$ \\
Vidian Nerve & $1(1.1)$ & 0 & 0 & $1(1.1)$ & 0 & 0 \\
\hline
\end{tabular}

ICA in $40.38 \%(n=21 / 52)$ of cases (left $=15.38 \%)$; right $=25.0$ $\%), \mathrm{MN}$ in $9.62 \%(\mathrm{n}=5 / 52)$ of cases (left $=5.77 \%$; right $=$ $3.85 \%$ ). The intrasinus septa did not attach to the $\mathrm{VN}$ in male specimens (Table VII).

The attachment of the sphenoidal sinus intersinus septa to the ST varied depending on the type of the sinus observed. The intersinus septa attached to the floor of ST in $32.4 \%$ of cases and these cases were observed in sellar and post-sellar types of the sinus. In the pre-sellar and sellar sinus types; the intersinus septa attached to the anterior wall (tuberculum sellae) of the ST in $16.2 \%$ of cases. The incidence of the intersinus septa attached to the posterior wall (dorsum sellae) of the ST was observed in $8.1 \%$ of cases and these were observed in only post-sellar sphenoidal sinuses. The intersinus septa attached to both the floor and the anterior wall of the ST in $43.2 \%$ of cases in sellar and post-sellar sphenoidal sinuses. There were no cases of the sphenoidal sinus septa attached to both the floor and posterior wall of the ST observed. The attachment of intrasinus septa to the ST had no relationship with the classification of the sphenoidal sinus. 
Dominance of the sinus. It was noted that; where the septum deviated to the left, the right sphenoidal sinus became dominant, and visa versa. The right sphenoidal sinus was dominant in $30 \%$ of cases and the left sinus in $22.5 \%$ of cases. It was also noted that; no two sides had the same septation pattern in one specimen; meaning, there were no similarities bilaterally observed in all of the studied specimens.

\section{DISCUSSION}

Endoscopic surgical approaches used to gain access to neurovascular structures at the base of the skull via paranasal sinuses and beyond their boundaries have become popular in recent years (Kapur et al.). The greater the extent of variations of the sphenoidal sinus and its septation, the greater the possibility of complications and risk of damage to vital related neurovascular structures during transsphenoidal approaches. If the sphenoidal sinus septa are not carefully removed, related structures may sustain injuries, especially in incidences of variation in the attachments of the septa.

Commonly the sphenoidal sinus is divided by a single intersinus septum into two parts; however, the presence of more than one septum completely separating the sinus has been reported in this study and by other authors, such as Sareen et al., Hamid et al. and Awadalla et al. The presence of only one intersinus septum was found to be prevalent in this study with the incidence of $65 \%$ of cases compared to the occurrence of more than one septum and the absence of it, in $22.5 \%$ and $7.5 \%$ cases, respectively; and these findings were consistent with those reported by most authors (Table VIII). It has been reported by authors like Tan \& Ong and Fasunla et al.; that it is uncommon to find the intersinus septum located centrally, it usually bends towards the lateral walls of the sinus; and this study confirmed these findings with incidences of the intersinus septum located in the midline being $7.5 \%$, deviating to the right in $22.5 \%$ and to the left in $30 \%$ of cases. However; Rennie et al. reported the central intersinus septum occurring in $55.4 \%$ of cases and the incidence of right deviating septa being $18.3 \%$ and the left deviating septa being present in 16.8 $\%$ of cases (Table IX). It was noted that; the right sphenoidal sinus became dominant where the septum deviated to the left, and visa versa.

Intrasinus septa further complicates the sphenoidal sinus; these projections which varied greatly morphologically were not present in only $6.7 \%$ of cases in this study and these findings were lower compared to those by Rennie $e t$ al. who recorded $40.7 \%$ and $44.6 \%$ of cases on the left and the right sides, respectively; this may be due to that the study by Rennie et al. was a paediatric sample in comparison with the adult sample indicated in other studies (such as the present one). Thus, intrasinus septa may be easier to observe radiologically in the adult patients as oppose to paediatric group or developmental in nature. The incidence of only a single septum occurring was found prevalent by Tan \& Ong with $65.6 \%$ of cases and the occurrence of more than one accessory septa

Table VIII Sphenoidal sinus intersinus septa orientation and proportions.

\begin{tabular}{|c|c|c|c|c|c|c|}
\hline \multirow[t]{2}{*}{ Author (year) } & \multirow[t]{2}{*}{ Country/Population } & \multirow[t]{2}{*}{ Modality } & \multirow[t]{2}{*}{ Sample size } & \multicolumn{3}{|c|}{ Orientation $(\%)$} \\
\hline & & & & Centra & Deviated to right & Deviated to left \\
\hline Tan \& Ong (2007) & Sing apore & Cadaveric & 48 & 16.6 & 27.1 & 56.3 \\
\hline Fasunla et al. (2012) & Nigeria & Radiographic & 110 & 18.2 & 26.4 & 43.6 \\
\hline Kapur et al. (2012) & Bosnia & Radiographic & 200 & 0 & 64.4 & 35.6 \\
\hline Chougule \& Dixit (2014) & North Karnataka & Radiographic & 30 & 29 & - & - \\
\hline Awadalla et al. (2015) & Egypt & Anatomical & 25 & 32 & - & - \\
\hline Rennie et al.(2017) & South Africa & Radiographic & 480 & 55.4 & 18.3 & 16.8 \\
\hline Current Study & South Africa & Cadaveric & 40 & 75 & 22.5 & \\
\hline
\end{tabular}

Table IX. Occurrence of the intersinus and intrasinus septa of the sphenoidal sinus.

\begin{tabular}{|c|c|c|c|c|c|c|c|c|}
\hline \multirow[t]{2}{*}{ Author (year) } & \multirow[t]{2}{*}{ Modality } & \multirow[t]{2}{*}{ Sample size } & \multicolumn{3}{|c|}{ Intersinus septa (\%) } & \multicolumn{3}{|c|}{ Intrasinus septa (\%) } \\
\hline & & & none & one & $>$ one & none & one & $>$ one \\
\hline Sareen et al. (2005) & Cadaveric & 20 & 0 & 20 & 80 & - & - & - \\
\hline Tan \& Ong (2007) & Cadaveric & $48(96)$ & 0 & - & - & 29.2 & 65.6 & 52 \\
\hline Hamid et al. (2008) & Radiological & 296 & 10.8 & 71.6 & 6.8 & - & 10.8 & - \\
\hline Kapur et al.(2012) & Radiological & 200 & 2 & 98 & - & - & - & - \\
\hline ELKammash et al. (2014) & Radiological & 182 & 13.2 & 70 & - & - & 8.3 & - \\
\hline Aw adalla et al. (2015) & Anatomical & 25 & 16 & 32 & - & - & 12 & - \\
\hline Aw adalla et al. (2015) & Radiological & 364 & 13 & 35 & 28 & - & 7 & - \\
\hline Rennie et al. (2017) & Radiological & 480 & 9.8 & 90.2 & - & $40.7 \mathrm{~L} ; 44.6 \mathrm{R}$ & - & - \\
\hline Current Study & Cadaveric & $40(80)$ & 75 & 28.9 & 20 & 6.7 & 45.6 & 47.8 \\
\hline
\end{tabular}


was recorded in only $5.2 \%$ of cases. However, the current study found the occurrence of more than one accessory septa (47.8\%) to be slightly higher compared to the occurrence of one intrasinus septum (45.6\%) (Table IX).

The sphenoidal sinus intersinus and intrasinus septa may attach to sella turcica and the bony coverings of the internal carotid artery, optic nerve, maxillary branch of the trigeminal nerve and of the vidian nerve located in the walls of the sinus. In this study, the intersinus septa did not attach to the optic nerve bony covering and the intrasinus septa did not attach in the bulges of both the optic and vidian nerves. Most authors, including Hamid et al. and Awadalla et al. recorded a high prevalence of septa attaching to the floor of the sella turcica (Table X). In this study, the incidence of the sinus septa attaching to sella turcica was prevalent for the intersinus septa $(46.25 \%)$ ), however, for the intrasinus septa, the attachment of the septa to the internal carotid artery was more prevalent $(52.63 \%)$ with attachments to the maxillary and vidian nerves uncommon with 1.25 of cases each (Table VII). Statistically, according to the tested correlations there was no association and no differences between the type and number of the sphenoidal sinus septa (intersinus and intrasinus) and sex, and between the left and right sides as well.
The complexity and uncertainty of the sphenoidal sinus intersinus septa makes it unreliable as a landmark to locate the midline of the sinus. Indeed radiography reveals a lot of information about the septa prior to endoscopic transsphenoidal approaches, but is it enough for surgical complications to be avoided? It is advisable that physicians and surgeons never temper with intrasinus septa where an alternative route is possible for surgical instruments through the sinus to reach the sella turcica. This will minimize possible risks of damaging vital neurovascular structures surrounding the sinus, even the intersinus septa needs to be removed with intensive care in order for such complication to be circumvented. It is not only about understanding the anatomy of the sphenoidal sinus septa, but also about gaining more knowledge on the complex variations of both the intersinus and intrasinus septa. This study records vital information on the variations of sphenoidal sinus septation in the South African population.

Limitations of this study: A shortage of cadaveric specimens resulted to only two racial groups being investigated.

Table X. Intersinus and intrasinus septa attachments on the sphenoidal sinus wall recorded by various authors (including findings from the current study)

\begin{tabular}{lccccc}
\hline Author (year) & \multicolumn{5}{c}{ Incidence of Intersinus Septa Attachments (\%) } \\
& ICA & ON & MN & VN & ST \\
\hline Unal et al. (2006) & 25.5 & 18 & - & - & - \\
Hamid et al. (2008) & 4.7 & - & - & - & 66.9 \\
Chougule and Dixit (2014) & 26.7 & 10 & - & - & - \\
Awadalla et al. (2015) & 20 & - & - & - & 64 \\
Ngubane et al. (2018) & 6.25 & - & 1.25 & 1.25 & 46.25 \\
& & Incidence of Intrasinus Septa Attachments (\%) \\
Hamid et al. (2008) & 6.8 & - & - & - & 4.1 \\
Chougule and Dixit (2014) & 23.3 & 6.7 & - & - & - \\
Awadalla et al. (2015) & 16 & - & - & - & 64 \\
Ngubane et al. (2018) & 52.63 & - & 5.26 & 2.63 & 26.32 \\
\hline
\end{tabular}

Key: Internal Carotid Artery (ICA); Optic Nerve (ON); Maxillary Nerve (MN); Vidian Nerve (VN); Sella Floor (SF)

\section{ACKNOWLEDGEMENTS}

The authors would like to extend their gratitude to the University of KwaZulu Natal, College of Health Sciences for funding this project, to Dr. Wilbert Sibanda and Dr. Oladapo Olagbegi for his assistance with statistical analysis and also to the technical staff (Mr. Celumusa Mbokazi, Mr. Prakash Mohanlal, Mr. Salem Kharwa and Mr. James H. Ngcongo) from the Department of Clinical Anatomy for their skilful technical assistance. 
NGUBANe, N. P.; LAZARUS, L.; RENNIE, C. O. \& SATYAPAL, K. S. Septación del seno esfenoidal. Investigación cadavérica. Int. J. Morphol., 36(4):1413-1422, 2018.

RESUMEN: El propósito de este estudio fue investigar la septación del seno esfenoidal en una población sudafricana y documentar la relación del número y la ubicación de los septos en relación a las estructuras íntimamente relacionadas con el seno. Los septos interseno e intraseno del seno, el número y las uniones de los septos se registraron a partir de cuarenta y cinco cadáveres. El septo interseno del seno esfenoidal se registró de la siguiente manera: Tipo 0 (tabique/septo ausente) en el 7,5\%, Tipo 1 (tabique/septo único) en el 65 $\%$ y Tipo 2 (tabiques/septos dobles) en el 22,5\% de los casos. La incidencia de septos intersenos desviados hacia la izquierda fue prevalente. Por lo tanto, el seno esfenoidal derecho fue dominante. La ocurrencia de septo intraseno se observó en el 93,3\% de los casos, con una mayor prevalencia en varones. Los septos intrasenos formaron cámaras, como cuevas, en las paredes del seno en un 65,6 $\%$ de los casos. La incidencia de septos intersenos que se adhieren a la silla turca (ST) $(46,25 \%)$ fueron prevalentes en comparación con los casos en que se unieron a la arteria carótida interna (ACI) $(6,25$ $\%)$, al nervio maxilar (NM) (1,25\%) y nervio vidiano (NV) (1.25\%). Sin embargo, los septos intersenos se adhirieron más a la ACI $(52,63$ $\%$ ) en comparación con su unión a otras estructuras neurovasculares (ST - 26,32\%; NM -5,36\% y NV - 2,63\%). Los cirujanos deben ser conscientes de las complejas variaciones anatómicas de la tabicación del seno esfenoidal cuando se realizan cirugías transesfenoideas endonasales endoscópicas.

PALABRAS CLAVE: Seno esfenoidal; Seno paranasal; Septación especímenes de cabeza de cadáver; Endoscopia endonasal transesfenoidal.

\section{REFERENCES}

Anusha, B.; Baharudin, A.; Philip, R.; Harvinder, S. \& Shaffie, B. M. Anatomical variations of the sphenoid sinus and its adjacent structures: a review of existing literature. Surg. Radiol. Anat., 36(5):419-27, 2014.

Awadalla, A. M.; Hussein , Y. \& ELKammash, T. H. Anatomical and radiological parameters of the sphenoid sinus among Egyptians and its impact on sellar region surgery. Egypt. J. Neurosurg., 30(1):1-12, 2015.

Casiano, R. R. Endoscopic Sinus Surgery Dissection Manual. A Stepwise, Anatomically Based Approach to Endoscopic Sinus Surgery. New York, Marcel Dekker, 2002.

Chong, V. F.; Fan, Y. F.; Lau, D. \& Sethi, D. S. Functional endoscopic sinus surgery (FESS): what radiologists need to know. Clin. Radiol., 53(9):650-8, 1998.

Chougule, M. S. \& Dixit, D. A cross-sectional study of sphenoid sinus through gross and endoscopic dissection in North Karnataka, India. $J$. Clin. Diagn. Res, 8(4):AC01-5, 2014.

ELKammash, T. H.; Enaba, M. M. \& Awadalla, A. M. Variability in sphenoid sinus pneumatization and its impact upon reduction of complications following sellar region surgeries. Egypt. J. Radio. Nucl. Med., 45(3):705-14, 2014

Fasunla, A. J.; Ameye, S. A.; Adebola, O. S.; Ogbole, G.; Adeleye, A. O. \& Adekanmi, A. J. Anatomical variations of the sphenoid sinus and nearby neurovascular structures seen on computed tomography of black Africans. East Cent. Afr. J. Surg, 17:57-64, 2012.
Hamid, O.; El Fiky, L.; Hassan, O.; Kotb, A. \& El Fiky, S. Anatomic variations of the sphenoid sinus and their impact on trans-sphenoid pituitary surgery. Skull Base, 18(1):9-15, 2008.

Hewaidi, G. H. \& Omami, G. M. Anatomic Variation of Sphenoid Sinus and Related Structures in Libyan Population: CT Scan Study. Libyan J. Med., 3(3):128-33, 2008.

Idowu, O. E.; Balogun, B. O. \& Okoli, C. A. Dimensions, septation, and pattern of pneumatization of the sphenoidal sinus. Folia Morphol. (Warsz), 68(4):228-32, 2009.

Kapur E, Kapidzic A, Kulonevic A, Sarajlic L, Sahinovic A, Sahnovic M. Septation of the sphenoid sinus and its clinical significance. Int. J. Coll. Res. Intern. Med. Public Health, 4(10):1793-802, 2012.

Kayalioglu, G.; Erturk, M. \& Varol, T. Variations in sphenoid sinus anatomy with special emphasis on pneumatization and endoscopic anatomic distances. Neuroscience (Riyadh), 10(1):79-84, 2005.

Lazaridis, N.; Natsis, K.; Koebke, J. \& Themelis, C. Nasal, sellar, and sphenoid sinus measurements in relation to pituitary surgery. Clin. Anat., 23(6):629-36, 2010

Lu, Y.; Pan, J.; Qi, S.; Shi, J.; Zhang, X. \& Wu, K. Pneumatization of the sphenoid sinus in Chinese: the differences from Caucasian and its application in the extended transsphenoidal approach. J. Anat., 219(2):132-42, 2011

Rennie, C.; Haffajee, M. R. \& Satyapal, K. S. The morphology of the sphenoid air sinus from childhood to early adulthood (1 to 25 years) utilizing 3D reconstructed images. Int. J. Morphol., 35(4):1261-9, 2017.

Sareen, D.; Agarwal, A. K.; Kaul, J. M. \& Sethi, A. Study of sphenoid sinus anatomy in relation to endoscopic surgery. Int. J. Morphol., 23(3):261-6, 2005.

Singh, I.; Goyal, S.; Bisht, S. \& Lakshmi. ICA Injury in sphenoid sinus during nasal endoscopic sinus surgery-A case report. J. Otolaryngol. ENT Res., 5(2):00133, 2016.

S`tokovic, N.; Trkulja, V.; Dumic-Cule, I.; C`ukovic-Bagic, I.; Lauc, T.; Vukicevic, S. \& Grgurevic, L. Sphenoid sinus types, dimensions and relationship with surrounding structures. Ann. Anat., 203:69-76, 2016.

Tan, H. K. \& Ong, Y. K. Sphenoid sinus: an anatomic and endoscopic study in Asian cadavers. Clin. Anat., 20(7):745-50, 2007.

Unal, B.; Bademci, G.; Bilgili, Y. K.; Batay, F. \& Avci, E. Risky anatomic variations of sphenoid sinus for surgery. Surg. Radiol. Anat., 28(2):195201, 2006.

Van Cauwenberge, P.; Sys, L.; De Belder, T. \& Watelet, J. B. Anatomy and physiology of the nose and the paranasal sinuses. Immunol. Allergy Clin. North Am., 24(1):1-17, 2004.

Vidya, C. S. \& Raichurkar, K. Anatomic variation of sphenoid sinus in mysore based population: CT scan study. Int. J. Anat. Res, 3(4):16114, 2015.

\section{Corresponding author:}

Professor KS Satyapal

Department of Clinical Anatomy

School of Laboratory Medicine and Medical Sciences

College of Health Sciences

University of KwaZulu-Natal

Private Bag X54001

Durban

4000

SOUTH AFRICA

Email: satyapalk@ukzn.ac.za

Received: 29-05-2018

Accepted: 22-08-2018 